\title{
Intellectual Property Valuation Decision Support System for University Research Output: A Conceptual Model
}

\author{
Kamarulzaman Ab Aziz ${ }^{1}$, Hezlin Harris ${ }^{1}$ and Nor Azlina Ab. Aziz ${ }^{2}$ \\ ${ }^{1}$ Faculty of Management, Multimedia University, Cyberjaya, Selangor, Malaysia \\ ${ }^{2}$ Faculty of Engineering and Technology, Multimedia University, Melaka, Malaysia
}

\begin{abstract}
Commercializing university research outputs or intellectual property is an imperative facet in the National Economic Model of the 10th Malaysian Plan (2011-2015) whereby innovation-based economy is the vehicle identified to drive Malaysia into becoming a high-income nation. A vital aspect of this innovation-based economy is Intellectual Property (IP) and its strategic management in the preliminary commercialization phase. One of the critical components of strategic management of IP is the valuation process. In order to capture and capitalize the IP resulting from university research, valuing the IP becomes a significant juncture on the road to exploitation and commercialization. This paper explores the aspects of IP valuation practices among Malaysian universities. It is found that IP valuation generally was done by external consultants or committees. This paper suggests that technology development provides an opportunity for enabling the researchers themselves with the capability to do the IP valuation.
\end{abstract}

Keywords: Intellectual Property; Valuation; Decision Support Systems; University.

\section{Introduction}

Globally, the importance of universities and their research, development as well as commercialization ( $\mathrm{R}, \mathrm{D} \& \mathrm{C})$ activities has been widely recognized (Candell and Jaffe, 1999; Ndonzuau et al, 2002). Previously, the focus had been primarily on R\&D; however, more recently according to Djokovic and Souitaris (2008), there is an increasing shift towards the inclusion of commercialization activities. Researchers in the universities produce innovations as a result of their research activities which in turn can be exploited commercially. However, the transformation from research and development into commercialization is a path strewn with many pitfalls.
When commercializing university's researches, there are three main strategies commonly applied: patenting or licensing, contract research and the creation of university spinouts (USOs) companies (Kroll and Liefner, 2008). Commercialization activities are bred and grown in these university research environments. The industries may not have the capacity to integrate and exploit the knowledge generated through the university research. Thus, there is an overriding fact that the significance of university research outputs has caught the attention of the industry players where they are now relying heavily on the university research results (Fabrizio, 2006) and they are willing to spend a greater share of their $R \& D$ dollars on university-

Copyright (C) 2012 Kamarulzaman Ab Aziz, Hezlin Harris and Nor Azlina Ab. Aziz. This is an open access article distributed under the Creative Commons Attribution License unported 3.0, which permits unrestricted use, distribution, and reproduction in any medium, provided that original work is properly cited. Contact author: Kamarulzaman Ab Aziz E-mail: kamarulzaman.aziz@mmu.edu.my 
based research projects (Berkovitz and Feldman, 2007). Their observation seems to be supported by earlier studies carried out both in the UK and the US (UNICO, 2001; AUTM, 2002).

Commercializing university research outputs or intellectual property is an imperative facet in the National Economic Model (NEM) of the 10th Malaysian Plan (2011-2015) whereby innovation-based economy is the vehicle identified to drive Malaysia into becoming a high-income nation (Economic Planning Unit, 2010). A vital aspect of this innovation-based economy is Intellectual Property (IP) and the ancillary issues that arise from it, such as the creation, protection, management and commercialization aspects. These factors play an important role in the National Intellectual Property Policy's ultimate aim which is to develop a vibrant IP industry as a driver for innovation and creativity that is essential in sustaining Malaysian's economic growth.

Valuing an IP is the most significant facet in IP commercialization. When valuing an IP, experts of the pertinent field can utilize either quantitative or qualitative or both approaches to arrive to a solution. A quantitative approach can be expressed using a numerical variable such as the cost incurred to produce the IP while a qualitative approach may be of a subjective matter to the experts and is not generally expressed in a numerical term. For example, the state of the economy can be identified as a qualitative variable which entails subjective evaluation. Reilly (2009) exerts that the state of the economy has an influence to the valuation variables in the income-based method; and it should be adjusted when valuing the IP. Hence, this paper attempts to explore the aspects of IP valuation practices among Malaysian universities and proposes a technological solution that can enable researchers or innovators to do the valuation of their innovations towards commercialization.

\section{Intellectual Property Valuation}

According to World Intellectual Property Organization (WIPO), intellectual property (IP) refers to creations of the mind: inventions, literary and artistic works, and symbols, names, images and designs used in commerce. IP is divided into five categories: i) Industrial property, which includes inventions (patents), ii) trademarks, iii) industrial designs, iv) geographic indications of source and v) Copyright, which includes literary and artistic works such as novels, poems and plays, films, musical works, artistic works such as drawings, paintings, photographs and sculptures, and architectural designs. Rights related to copyright include those of performing artists in their performances, producers of phonograms in their recordings and those of broadcasters in their radio and television programs. IP can also be regarded as the more "tangible" part of intellectual capital (IC), as IP consists of patents, copyrights, trademarks, etc. that can be more easily valued than the more intangible IC assets (Bollen et al, 2005).

In order to capture and capitalize the IP that is spun out of university research, valuing the IP becomes a pertinent stage on the road to exploitation and commercialization. Valuation of IP is not an accounting operation but rather an attempt to reconcile information pertaining to a given IP or business project, such as development costs, expectation of income, comparative advantages and market data for the purpose of making better strategic decisions. The valuation process can take into consideration the impact of IP not only on projects and products but also on the business operation and on its competitive position as a whole (Roy, 2004).

There is a plethora of research concerning methods in valuing intellectual property (IP). Various models can be justified under many different circumstances. 
Within each of the various models there are different variations that can be applied. The choice of model significantly influences the resultant valuation, estimates and reflects the business' goals and concerns regarding the IP (Matsuura, 2004). The established methods for valuing IP can be categorized into four main models:

i) The cost-based models: A cost-based valuation model focuses on the costs incurred to develop the IP and intangible assets. It provides an estimate for the value of the asset that is tied to the cost to create or acquire the asset. The cost approach, that is the cost to create or recreate the asset; we look at what we spent on developing the IP and what another company might spend if they were to invent it from scratch (Pitkethly, 2002; Matsuura, 2004; Goldheim et. al, 2005; Reilly, 2009; Ernst, Legler and Lichtenthaler, 2010).

ii) The market-based models: Marketbased valuation models estimate the value of IP assets by looking to the marketplace. The sales of comparable intellectual property, where a 'somewhat' similar deal could be used for the purpose of comparison (Pitkethly, 2002; Matsuura, 2004; Goldheim et. al, 2005; Reilly, 2009; Ernst, Legler and Lichtenthaler, 2010).

iii) The income-based models: Make use of forecast future revenues to develop a current estimate of the asset value. It is based on the future economic benefits produced by the intellectual property, where we look at the projected incremental profits or costs savings from using the IP (Pitkethly, 2002; Matsuura, 2004; Goldheim et. al, 2005; Reilly, 2009; Ernst, Legler and Lichtenthaler, 2010).

iv) The option model: It is among the latest discovery as the IP valuation technique. This model combines the decision tree, real option, binomial, Black-Scholes and the Monte Carlo methods (Lagrost et. al.,
2010). It is an option -- choice that can be exercised at a specific time, but need not be exercised. Owners of IP have a variety of choices about the development and commercialization of their asset. The choices include what form of IP to invoke, licensing, pricing, enforcing their legal rights, etc. According to Chaplinsky (2002), this method recognizes that a patent has intrinsic value based on its projected cash flows discounted at the opportunity cost of capital for the owner of the patent. In other words, option models attempt to estimate economic values for each of the choices (Van den Berg, 2002; Matsuura, 2004; Ernst, Legler and Lichtenthaler, 2010). Studies by Chang, Hung and Tsai (2005) use cautious views of how volatility impacts the value of IP. However, the option model suffers from several limitations such as there exists an inexact mapping of the assumptions or inputs between option pricing theory and real option application (Chang, Hung and Tsai, 2005) and the estimation in volatility is actually difficult in practice (Sudarsanam, Sorwar and Marr, 2003).

Valuing intellectual assets poses a challenge to not only science and technology analysts but also policy makers. There is a level of subjectivity when it comes to a decision making process with regards to managing IP especially in valuing an IP that is generated through university research. More and more quantitative indicators are used to assess the quality and quantity of university generated scientific work and its impact on technological development and innovation of the "Third Stream" activities (specifically referring to universities active engagement with industry) as stated by Meyer and Tang (2007). Following are some of the commonly cited challenges to IP valuation according to a study by Mergermarket (2008):

- Time constraints

- Understanding the impacts of the legal issues on the value of the IP 
- Lacking sufficient resources for the valuation process

Mergermarket (2008) also identify the consequences of not doing IP valuation properly: i) failure to identify IP risks, ii) failure to secure rights to the targeted IP, iii) overvalued the IP, iv) failure to exploit the IP, v) failure to identify IP potentials and vi) undervalued the IP.

\section{Insights from a Research University}

Universiti Teknologi Malaysia (UTM), with its main campus in Johor and a smaller campus in Kuala Lumpur, is one of the original research universities. It is one of the major universities in Malaysia, with 2000 academic staff, around 21000 undergraduate and 8000 postgraduate students. It has 14 faculties, 1 language academy, 5 schools for graduate studies and 1 school for continuing education. Its history can be traced back to 1904 as the country's first technical school. The school evolved into a college then an institute, and on 1st April 1975 it was upgraded to Universiti Teknologi Malaysia. UTM's mission is to lead in the development of creative and innovative human capital and advanced technologies that will contribute to the nation's wealth creation.

UTM won the National Intellectual Property Award (organization category) three times since the award was introduced in 2006. Among the Malaysian universities, Universiti Teknologi Malaysia (UTM) has had the highest commercialisation output as measured by the four domains presented in Table 1. Furthermore, UTM was the first university in Malaysia to establish a technology transfer company Unitechnologies.
UTM's research, development and commercialization activities are guided by a number of policies, including IP Commercialization Policy, Intellectual Property Policy and Research \& Development Policy. These policies are intended to provide support, guidance and framework to enhance researchers' productivity. These policies are implemented through separate structures that are geared specifically towards research and development on one hand and commercialization on the other.

With the new organizational restructuring in late 2010, UTM aspires to increase not only the number of IP exploitation but also innovation. The shift of the emphasis to innovation is taken in light of the disparity in the market demand in Asia and the West. In the commercialization process, UTM has long been heavily dependent on the external parties; but it is now slowly phasing out its reliance on external parties by educating its own inventors through a series of related courses. Innovation and Commercialisation Centre (ICC) is UTM's one stop centre for technology innovation and commercialisation. ICC was set up in June 2010 to replace the Bureau of Innovation and Consultancy (BIC). This provides a clear focus on efforts to produce innovations and their commercialisation. The ICC works strategically with the faculties, research alliances and centres of excellence in UTM to identify, develop and commercialise UTM's innovations. ICC is now responsible for Intellectual Property (IP) management and exploitation which were formerly under the jurisdiction of the Research Management Centre (RMC). There are two sub-units in the ICC which are responsible for innovation and commercialisation aspects; namely, Innovation and Commercialisation. 
Table 1: University Research Commercialisation until August 2008 (Source: MOHE, 2008)

\begin{tabular}{|c|c|c|c|c|c|}
\hline Universities & Patent & Trademark & $\begin{array}{c}\text { Total } \\
\text { Commercialised } \\
\text { Products }\end{array}$ & $\begin{array}{l}\text { Total R\&D with } \\
\text { Potential for } \\
\text { Commercialised } \\
\text { Products }\end{array}$ & $\begin{array}{l}\text { Total } \\
\text { No. of } \\
\text { IP }\end{array}$ \\
\hline $\begin{array}{l}\text { Universiti } \\
\text { Teknologi Malaysia } \\
\text { (UTM) }\end{array}$ & 9 & 28 & 6 & 110 & 153 \\
\hline $\begin{array}{l}\text { Universiti Putra } \\
\text { Malaysia (UPM) }\end{array}$ & 12 & 27 & 16 & 15 & 70 \\
\hline $\begin{array}{l}\text { Universiti } \\
\text { Kebangsaan } \\
\text { Malaysia (UKM) }\end{array}$ & 3 & 20 & 0 & 33 & 56 \\
\hline $\begin{array}{l}\text { Universiti Malaya } \\
\text { (UM) }\end{array}$ & 0 & 11 & 3 & 31 & 45 \\
\hline $\begin{array}{l}\text { Universiti Sains } \\
\text { Malaysia (USM) }\end{array}$ & 11 & 4 & 15 & 9 & 39 \\
\hline $\begin{array}{l}\text { Universiti } \\
\text { Teknologi Mara } \\
\text { (UiTM) }\end{array}$ & 5 & 22 & 8 & 0 & 35 \\
\hline $\begin{array}{l}\text { Universiti Malaysia } \\
\text { Pahang (UMP) }\end{array}$ & 0 & 0 & 1 & 29 & 30 \\
\hline $\begin{array}{l}\text { Universiti Malaysia } \\
\text { Sabah (UMS) }\end{array}$ & 0 & 0 & 0 & 26 & 26 \\
\hline $\begin{array}{l}\text { Universiti Utara } \\
\text { Malaysia (UUM) }\end{array}$ & 0 & 0 & 0 & 21 & 21 \\
\hline $\begin{array}{l}\text { Universiti Tun } \\
\text { Hussein Onn } \\
\text { Malaysia (UTHM) }\end{array}$ & 0 & 0 & 3 & 16 & 19 \\
\hline $\begin{array}{l}\text { Universiti Malaysia } \\
\text { Sarawak (UNIMAS) }\end{array}$ & 0 & 8 & 0 & 4 & 12 \\
\hline $\begin{array}{l}\text { Universiti Islam } \\
\text { Antarabangsa } \\
\text { Malaysia (UIAM) }\end{array}$ & 0 & 2 & 2 & 4 & 8 \\
\hline $\begin{array}{l}\text { Universiti } \\
\text { Pendidikan Sultan } \\
\text { Idris (UPSI) }\end{array}$ & 0 & 0 & 0 & 8 & 8 \\
\hline $\begin{array}{l}\text { Universiti Malaysia } \\
\text { Terengganu (UMT) }\end{array}$ & 0 & 0 & 2 & 4 & 6 \\
\hline $\begin{array}{l}\text { Universiti Malaysia } \\
\text { Perlis (UniMAP) }\end{array}$ & 0 & 0 & 2 & 3 & 5 \\
\hline $\begin{array}{l}\text { Universiti Teknikal } \\
\text { Malaysia Melaka } \\
\text { (UTEM) }\end{array}$ & 0 & 0 & 0 & 0 & 0 \\
\hline Total & 40 & 122 & 58 & 313 & 533 \\
\hline
\end{tabular}




\section{ICC - Innovation Unit:}

The Innovation Unit provides assistance to the UTM inventors, innovators and entrepreneurs by making their ideas more commercially successful through networking with industry and affiliate partners. Traditionally, the focus was centred on commercialisation only but with the new structure, Innovation Unit is held responsible to encourage innovation among UTM lecturers as well as students. Innovation Point is one of the initiatives taken by the Unit. The Innovation Point takes care of the incubation and the Product Development Technology (PDTC). In order to accelerate the pursuit of innovation, the Innovation Point takes a more proactive initiative by meeting up with the faculty members and also Research Alliances (RA) to find out the types of research that the researchers are doing.

\section{ICC - Commercialisation Unit:}

The Commercialisation Unit involves in assisting the UTM inventors, innovators and entrepreneurs in the formation of spin-off start-ups, joint ventures and partnerships. The unit also conducts related trainings and courses such as financial planning for the entrepreneurs to equip them with knowledge on how to construct their business plans etc. Although the business plan can be outsourced to external parties, the unit views that it is pertinent that the entrepreneurs themselves explore and learn about the target market, market size and share and other industry players.

A clear and comprehensive approach to IP management is also in place. The Unit is in charge of recording disclosure forms for researchers who would like to voluntarily disclose their inventions. The Unit then seeks assistance from the external parties such as the patent agents to do patent search. The patent agent will advise the Unit to proceed for the patent application if the invention is found to be novel. Subsequently, the invention will undergo a series of evaluation from both internal and external committees. There are two evaluation phases within the internal committee: 1) the Commercialisation Unit which consists of ICC members and 2) the representatives from the Research Alliances (RA) who are related to the field of technology. The next stage includes evaluation from the external parties such as SME Corporation, MTDC, investment bankers and industry partners.

The internal committee which consists of RA must have a minimum number of 7 members including one chairman. The process of evaluation begins by obtaining the number of IP targets for half of the year. Then based on the evaluation, the number is usually reduced. Feedbacks from the external parties are taken into consideration whether the IP should be obtained or should not be obtained. If the invention does not receive favourable feedback from the external parties, it is returned to the inventor for further improvement in terms of value-added or design wise.

With the establishment of ICC within the new structure, UTM aspires to increase not only the number of IP exploitation but also innovation. The shift of emphasis to innovation is taken in light of the disparity in the market demand in Asia and the West. In Asia, the industry players are only interested in readymade products. The impacts of the new structure can be seen in the accumulated IPs as shown in Table 2. 
Table 2: Accumulated IP until 5/1/2011 (Source: Dr. Kamariah Ismail, UTM)

\begin{tabular}{|l|l|c|}
\hline \multicolumn{2}{|c|}{ Category } & Total \\
\hline Patent & Filing & 234 \\
\cline { 3 - 3 } & Granted & 15 \\
\hline Copyright & 329 \\
\hline Industrial Design & 3 \\
\hline Trademark & 40 \\
\hline Utility Innovation & 5 \\
\hline \multicolumn{2}{|c|}{ TOTAL } & 626 \\
\hline
\end{tabular}

\section{From Creation to Exploitation - the Innocom:}

Currently, ICC relies heavily on the patent agents to do patent search. However, ICC aims to educate UTM inventors to do their own patent search, market search etc. through a series of related courses. The inventors are also expected to think one step ahead in the design and explore the commercial aspects of their inventions. These actions are employed to transform the mindset of the inventors where traditionally the inventions were purely created out of curiosity or through journals.

The shift of dependence from the external agents is also seen in the establishment of a scoring system known as Innocom. This evaluation process is taken place within the RA. The implementation of the Innocom scoring system is also part of the aggressive move towards IP exploitation. Upon obtaining the scoring point, the inventors will attach the scoring form together with the disclosure form and submit it to the ICC.

According to the scoring system, each invention is evaluated and rated based on the following areas: commercial potential, competitors, local or global market value, target market and, importantly, motivation of the inventors. A threshold of 50 points is required for inventions that have the potential to be patented. The motivation of the inventors will determine whether a company should be formed or proceed with joint venture or simply license the invention to existing company. The inventors are proposed to form a company if the score points are as high as $80 \%$. The inventors are considered risk averse if the score points are between $70 \%-80 \%$. If this is the case, inventors are suggested to license out or joint venture. In the company formation, inventors can only be one of the board of directors not the managing director. They, however, are given a share in the company. The ICC's workflow is shown in Figure 1.

The implementation of the Innocom scoring system is also part of the aggressive move towards IP exploitation. The emphasis on scoring is a result of the concern that prior focus on IP filing without similar emphasis on commercialization was backfiring. The cost of filing IP can come up to thousands of dollars with further thousands for maintaining the IP rights. These investments more often than not in the past have been in vain as no commercialization resulted from the patents. The scoring is intended to ensure commercial viability of the product is tested before proceeding for filing for IP and subsequently pushed towards commercialization.

A major obstacle to transforming patents to commercialization is the entrepreneurial skill gaps among the researchers. One of the entrepreneurial skills commonly lacking among the researchers is the skill to properly value their innovations which is a key step towards successful commercialization. UTM relies heavily on external consultants for a number of their IP management activities including patent search and valuation. According to the representative of the Innovation Commercialization Unit, the ideal would be to have the researchers to do their 
own patent search, market search and valuation. Motivated by the challenge faced by UTM, this paper attempts to propose the development of Decision Support System (DSS); a technological solution in facilitating them to value their IP. UTM is one of the oldest universities in Malaysia, if they find IP valuation a major challenge, then arguably the younger universities in Malaysia would find valuation as a significant challenge as well. The proposed DSS is expected to be a stimulant in driving more university researchers to not only pursue research activities but to progress forward to commercializing of their research output. This will help ensure the researchers/ inventors to be more engaged in the commercializing of their IP, and ultimately transforming them into researchers that will think ahead in terms of the commercialization when designing their research projects. When the researchers perform the valuation themselves, they will see the potential and thus it will be easier to ensure their commitment in the commercialization efforts.

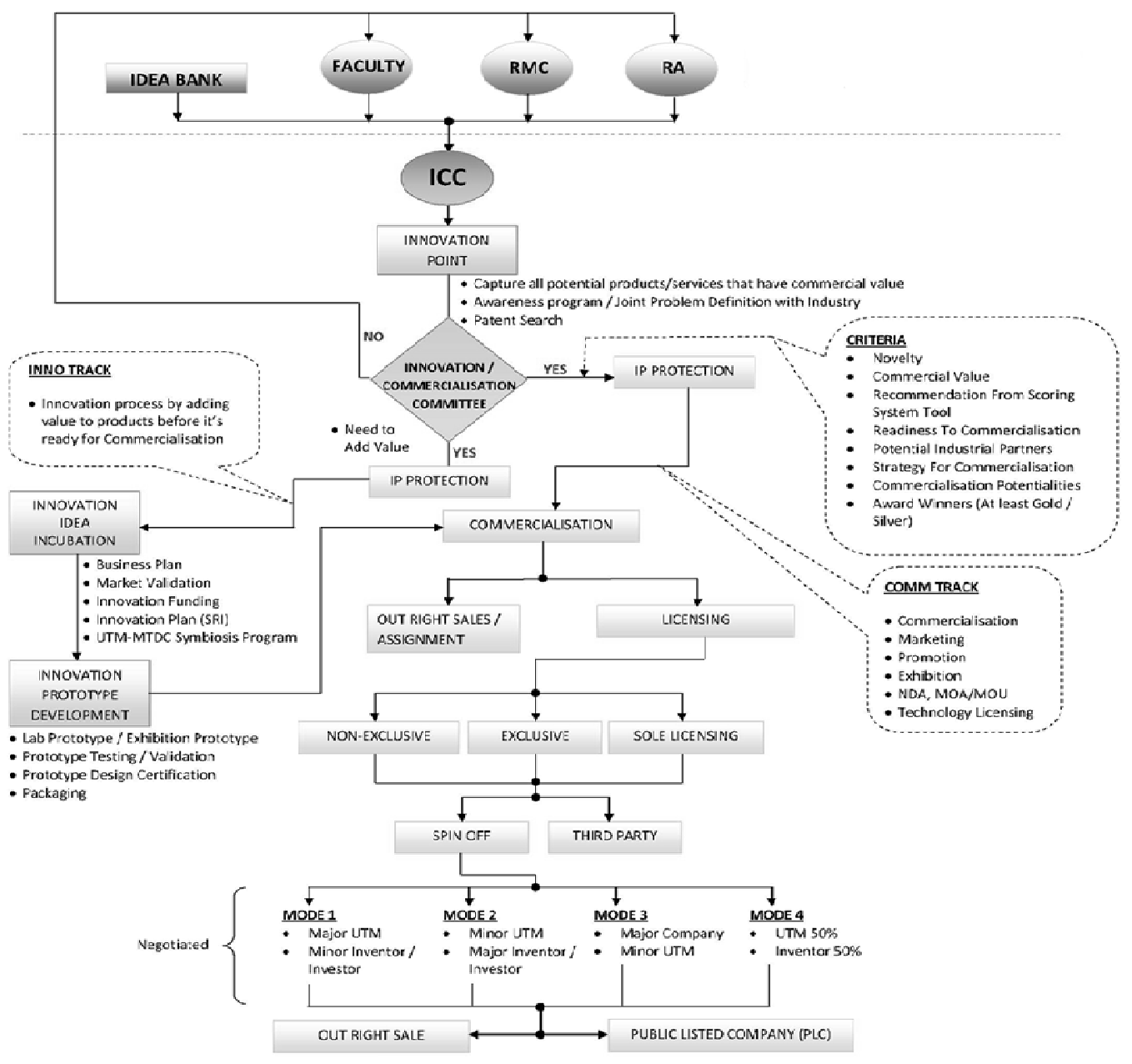

Fig. 1: ICC's Workflow (Source: http://www.icc.utm.my/en/corporate-info.html) 


\section{Decision Support Systems (Dss)}

There is a level of subjectivity of risks and aspects in deciding which valuation method would best serve the interest of the organization and the IP itself. It is not simply a box-ticking option. Decision making is not always easy to do, especially when it involves complex problems and the decision makers have limited information, knowledge, experience or abilities (Eirman, Niederman and Adams, 1995). For effective decision making, the decision makers must be able to predict the outcome of each alternative as well, and based on all these items, determine which alternative is the best suited to the particular circumstance (Reason, 1990). According to Simon (1977), decision making is an essential and crucial function in organizations and good quality decisions lead to higher productivity, timely problem solving and better overall performance.

The need for sound and effective decision making has led to the development of numerous decision support systems (DSS). The advent of state of the art technologies has enabled organizations in decision making and problem solving processes. DSS are the technological solutions that evolve from the convergence of two areas - theoretical studies of organizational decision making and the development of information systems for decision making (Shim et. al., 2002). It can solve complex computations quickly and at a minimal cost, reduces dependence on external parties or many support staff and enhances the quality of the decision made. DSS are now extensively used in the medical sector (Graaf et al, 1997), environmental management (Salewicz and Nakayama, 2004), human resource management (Parker et al, 1994), operations management (Jager et $\mathrm{al}, 1989)$, new product development
(Kettelhut, 1991), strategic planning (Moormann and Lochte-Holtgreven, 1993) and many more.

According to Turban (1993), a standard DSS structure should encompass the following:

i) it assists but does not replace the decision maker, it neither tries to present the "answers" nor to enforce a predetermined series of analysis;

ii) it assists semi-structured decisions, where some elements of the analysis can be systematized for the computer, but where the decision maker's wisdom and judgment are needed to dominate the process;

iii) it blends modelling techniques with database and presentation mechanisms;

iv) it emphasizes ease of use, user friendliness, user control, and flexibility and adaptability; and

v) it assists all stages of decision making.

A DSS is a knowledge integrated computerbased program that analyzes business data as input and recommends decision making options as output. The input data is processed using algorithms and modeling techniques designed for specific problems and needs of the decision makers. Generally, there are four main components in a DSS architecture (refer Figure 2) which includes the input (database or the information and characteristics associated to IP), the model (data is processed based on the parameters set by the user), the output (solution generated by the system) and the user interface (the portal which allows the user to interact with the computer). 


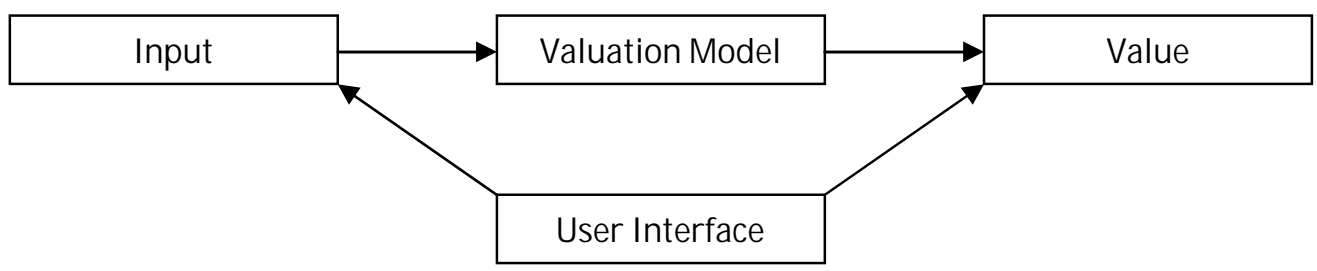

Fig. 2: Generic DSS Architecture for IP Valuation

The basic elements in the "input" should comprise of the relevant quantitative and qualitative characteristics of IP and information required for the three main valuation methods in this study. The inputs shall also be known as the common valuation elements. The list of suggested inputs (derived from literature) is listed in Table 3. The DSS model will then analyze the inputs according to the user specifications and provide the solution to the user with regards to the cost-based, market-based and incomebased as the outputs. The DSS model is not merely a compilation of information but it can be used to invoke answers to the "whatif" questions which are performed using sensitivity analysis. Sensitivity analysis tests the effect on the output variable of systematic changes in input variables in the form of a mathematical modeling. For a given uncertainty in the input variables, sensitivity analysis is utilized to investigate the robustness of the result. It is also often referred to as post-optimality analysis. It is a study of how sensitive an optimal solution is to model assumptions and to data changes. This allows the user to experiment various scenarios, evaluate the inputs and deal with constraints while maximizing or minimizing the objective functions. The essence of DSS is that it should be flexible enough for the user to modify or change the parameters.

The DSS model should also cater the qualitative characteristics of the IP such as the state of the economy, the uniqueness, functionality or the exploitation capability of the IP to name a few. Hagelin (2002) proposes five elements in a valuation approach. The elements comprise of factors which influence the IP value (measured by scoring criteria), merits assigned to the scoring criteria (known as the scoring system), technique employed by the scoring system (measured by the scoring scale), factors to be applied to the scoring system in order to distinguish the significance of the scoring criteria (also known as the weighting factor) and finally the decision table which is the composite score for the IP being analyzed obtained through a combination of the scoring criteria, scoring system and weight.

Lagrost et. al. (2010) depicts a comprehensive decision process of IP valuation methods for the evaluators to consider. The evaluators have to first go through all the questions - "Why, What, For what, For whom and How" - as the basis that would rationalize the ultimate IP valuation outcomes. Those questions include the quantitative and qualitative aspects pertaining to the global management strategy and IP management and exploitation, the purpose of the IP valuation, the target audience as the shareholders or investors, the type of IP being evaluated and the form of IP right to choose from. Inspired from the study of Hagelin (2002) and Lagrost et. al. (2010), this paper proposes a conceptual model for the development of a DSS in valuing IP. 
Table 3: DSS Input

\begin{tabular}{|l|l|}
\hline \multicolumn{1}{|c|}{ Common Valuation Elements (Inputs) } & \multicolumn{1}{c|}{ Source } \\
\hline Estimated income stream over the IP's useful life & (Chaplinsky, 2002; Pitkethly, 2002) \\
\hline Estimate of the duration of the IP's useful life & (Chaplinsky, 2002) \\
\hline Specific risk factors associated with the IP & (Chaplinsky, 2002; Chiesa, et. al., 2007) \\
\hline $\begin{array}{l}\text { Market value by reference to comparable market } \\
\text { transactions }\end{array}$ & $\begin{array}{l}\text { (Mard, Hyden, and Rigby, 2000; King, 2002; } \\
\text { Pitkethly, 2002; Roy, 2004) }\end{array}$ \\
\hline $\begin{array}{l}\text { Total cost incurred during the generation of the IP } \\
\text { including failures }\end{array}$ & $\begin{array}{l}\text { (Mard, Hyden, and Rigby, 2000; Chaplinsky, } \\
\text { 2002) }\end{array}$ \\
\hline $\begin{array}{l}\text { Total cost if the IP is to be re-constructed at the } \\
\text { present value of money }\end{array}$ & $\begin{array}{l}\text { (Mard, Hyden, and Rigby, 2000; Chaplinsky, } \\
\text { 2002; Samuel, 2007) }\end{array}$ \\
\hline $\begin{array}{l}\text { Total cost to construct an replica of the IP with } \\
\text { similar functions }\end{array}$ & $\begin{array}{l}\text { (Mard, Hyden, and Rigby, 2000; Chaplinsky, } \\
\text { 2002) }\end{array}$ \\
\hline Unique capability of the IP & (Reitzig, M., 2004; Chiesa, et. al., 2007) \\
\hline Expected rate of return of the IP & (Mard, Hyden, and Rigby, 2000) \\
\hline Functionality of the IP & (Smith and Hansen, 2002; Reilly, 2009) \\
\hline Degree of protection accorded to the IP & $\begin{array}{l}\text { (Park and Park, 2004; Hanel, 2006; Chiesa, et. } \\
\text { al., 2007) }\end{array}$ \\
\hline Exchange market value between two parties & $\begin{array}{l}\text { (Chaplinsky, 2002; Mard, Hyden, and Rigby, } \\
\text { 2000) }\end{array}$ \\
\hline Sales of similar IP in the past & (Ernst, Legler and Lichtenthaler, 2010) \\
\hline Exploitation capability of the IP & (Smith and Hansen, 2002) \\
\hline Developer's profit & (Reilly, 2009) \\
\hline
\end{tabular}

\section{A Conceptual Model}

Based on the discussion above, it is clear that there is an increasing need for improving the ability to do IP valuation among universities in Malaysia. In order to drive higher level of research commercialization among the university researchers, it is the belief of this paper that one of the key factors would be improving the ability among the researchers to do valuation of their research output. With the development in information systems, specifically DSS applications, this paper proposes a conceptual model for an IP valuation DSS. For simplicity, the acronym IPV-DSS will be used to represent an IP valuation decision support system throughout this paper. 


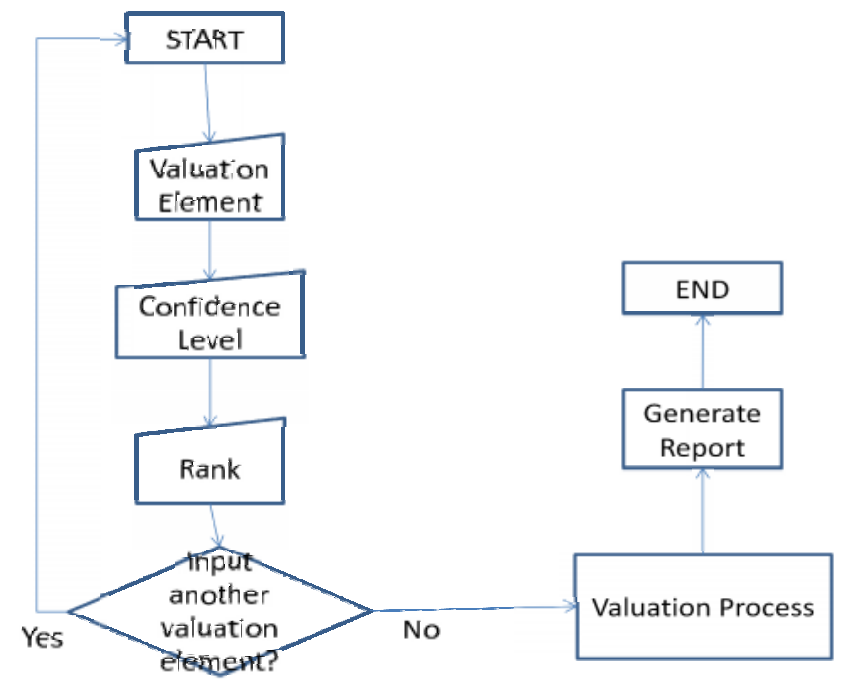

Fig. 3: IPV-DSS Process Flow Chart

Figure 3 above illustrates the process flow of the proposed IPV-DSS. The process starts with the researcher or the user entering the valuation elements data. There will be a number of valuation elements, such as the ones listed in Table 3. Each valuation element will correspond to a specific IP valuation model (i.e. cost-based, market-based or income-based). Generally, the valuation element data can either be a known fact, computed from collected data, estimation or projection based on some data plus assumption, educated guess work based on experience and knowledge, or pure guess work. The valuation element data may also include qualitative (e.g. uniqueness of the IP) or quantitative (e.g. estimated income stream over the IP's useful life) variables. 




Generate report;

\section{Fig. 4: IPV-DSS Valuation Process Algorithm}

Secondly, when entering in the valuation element data, the researcher will be required to indicate the quality of the data, measured by the level of confidence. The level of confidence (denoted as " $C$ ") will be used to control the impact of low quality data on the valuation calculation. It will also reflect the reliability of the collected data. For example, on a scale of 1 to 5 , where 1 indicates $100 \%$ confidence and 5 being $100 \%$ pure guess work. It is also the belief of this paper that beside assigning a confidence level to each valuation element, the researcher should also be given the ability to identify the importance of each valuation element; hence, the weight of the element via ranking procedures (denoted as " $R$ "). For example, the ranking for the weight can be indicated on a scale of 1 to 5 , where 1 indicates as extremely important and 5 as not important. When the researcher has incorporated all the valuation element data, the relevant data will be sorted and extracted for the valuation process. This will depend on the valuation model used. Once the information has been extracted and sorted, the calculation will be done using the valuation formula (an equation to compute an IP value using cost, income or market-based model). Figure 4 provides the algorithm for the valuation process.

The sort function will first extract the individual Valuation Element and identify the corresponding valuation model (cost-based, market-based, income-based, etc) for the element. The determination of the element to model is done when designing the IPV-DSS. Next, for each element the sort function will also attach the Confidence Level $(C)$ and Rank $(R)$ specified by the researcher. At the end of the sort function, the data will be ordered and flagged for the relevant formula depending on the corresponding model. The sorted information will then be stored in the system memory as shown in Table 4. Each different valuation model will have an individual formula that will be used as the computing algorithm to calculate the IP value. Figure 5 provides an example of a formula based on the IP valuation Cost-based model. 
Table 4: IPV-DSS Sort Function

\begin{tabular}{|c|c|c|c|}
\hline Valuation Element $\left(\boldsymbol{X}_{\boldsymbol{i}}\right)$ & Valuation Formula & Confidence Level $\left(\boldsymbol{C}_{\boldsymbol{i}}\right)$ & Rank $\left(\boldsymbol{R}_{\boldsymbol{i}}\right)$ \\
\hline$X_{1}$ & $\begin{array}{c}\text { Corresponding Valuation } \\
\text { Model }\end{array}$ & $C_{1}$ & $R_{1}$ \\
\hline$X_{2}$ & $\begin{array}{c}\text { Corresponding Valuation } \\
\text { Model }\end{array}$ & $C_{2}$ & $R_{2}$ \\
\hline$\cdot$ & $\cdot$ & $\cdot$ & $\cdot$ \\
\hline$\cdot$ & $\cdot$ & $\cdot$ & $R_{n}$ \\
\hline$X_{n}$ & $\begin{array}{c}\text { Corresponding Valuation } \\
\text { Model }\end{array}$ & $C_{n}$ & \\
\hline
\end{tabular}

$$
Y=X_{1}+X_{2}+\ldots+X_{n}
$$

Where, $Y=$ IP Value

$X_{i}=$ Value of the $i^{\text {th }}$ Valuation Element

$n=$ to the $n^{\text {th }}$ ranking for $n^{\text {th }}$ valuation element

Fig. 5: Example of a Valuation Formula (Cost-Based Model)

The system will first compute the value


according to the different models. The user will then be given the option to generate other valuation ( Value $_{\text {Criteria }}$ ) based on either Rank $(R)$, Confidence Level $(C)$ or a combination of both. For example, the researcher may want to examine the IP value based on elements of high importance only (i.e. high $R$ value), or the researcher may want to explore the valuation based on elements with high quality data only (i.e. high $C$ value), or the researcher may want to investigate the valuation based on both criteria (i.e. high $R$ and high $C$ value or high $R$ and low $C$ etc). The system will then analyze the data and extract the solution according to the specified criteria. The solution will reveal an IP value based on the three valuation models. Once the researcher has finished generating the various valuation alternatives, the system will generate a report for the user and the whole process ends.

\section{Conclusion}

Due to the complexities in valuing an IP, this paper has attempted to incorporate various valuation elements into a systematic and structured technological solution i.e. IPV-DSS to ease the decision making process. An IPVDSS would be a very useful tool in driving more university researchers to not only pursue research activities but to progress forward to commercializing of their research output. It is however, important to realize that it should not be used as the ultimate solution as the researcher has to exert control on how the valuation process is carried out. It requires a thoughtful approach and a series of cross examinations among the competing alternatives. Not only that, it is imperative for the researcher to consider the variation in the valuation elements depending on the IP and the chosen IP rights. One size does not fit all. An effective decision maker should always evaluate the advantages and disadvantages of each solution as suggested by the DSS and then choose and implement the best solution.

\section{Acknowledgements}

We wish to acknowledge the anonymous reviewers for their valuable comments and insights. The Malaysian Ministry of Higher Education (MOHE) for the research grant (Fundamental Research Grant Scheme (FRGS) enabling this study to be carried out. Dr. Kamariah Ismail, the Deputy Dean for 
Commercialisation, Innovation and Commercialisation Centre, Universiti Teknologi Malaysia, for the interview and information shared. We also would like to thank Mr. D. Brown for assisting with the language editing.

\section{References}

AUTM (Association of University Technology Managers). (2002). AUTM Licensing Survey. Northbrook, Ill: AUTM.

Berkovitz, J. E. L. \& Feldman, M. P. (2007). "Fishing Upstream: Firm Innovation Strategy and University Research Alliances," Research Policy Vol. 36 (7): 930-948.

Bollen, L, Vergauwen, $\mathrm{P}$ \& Schnieder, S. (2005). "Linking Intellectual Capital and Intellectual Property to Company Performance," Management Decision, Vol. 43 (9): 1161-1185.

Candell, A. B. \& Jaffe, A. B. (1999). The Regional Economic Impact of Public Research Funding: a Case Study of Massachusetts. in L. M. Branscomb, F. Kodama \& R. Florida. Industrializing Knowledge. US, MIT Press: 510-530.

Chang, J. R., Hung, M. W. \& Tsai, F. T. (2005). "Valuation of Intellectual Property: a Real Option Approach," Journal of Intellectual Capital, Vol. 6 (3): 339-356.

Chaplinsky, S. \& Payne, G. (2002). "Methods of Intellectual Property Valuation," Charlottesville, Virginia: Darden University of Virginia, Pp. 1 - 12.

Chiesa, V., Frattini, F, Gilardoni, E., Manzini, R. \& Pizzurno, E. (2007). "Searching for Factors Influencing Technological Asset Value," European Journal of Innovation Management, Vol. 10 (4): 467-488.

Djokovic, D. \& Souitaris, V. (2008). "Spinouts from Academic Institutions: a Literature Review with Suggestions for Further Research," Journal of Technology Transfer, 33: 225-247
Economic Planning Unit. (2010). Available at Http:/ / Www.Epu.Gov.My/ Html/ Themes/ Ep u/ Html/ RMKE10/ Rmke10_English.Html. (Accessed: 22 June 2011)

Eirman, M. A., Niederman, F. \& Adams, C. (1995). "DSS Theory: a Model of Constructs and Relationships," Decision Support System, Vol. 14: 1-26.

Ernst, H., Legler, S. \& Lichtenthaler, U. (2010). "Determinants of Patent Value: Insight from a Simulation Analysis," Technological Forecasting and Social Change, Vol. 22 (1): 119.

Fabrizio, K. R. (2006). "The Use of University Research in Firm Innovation," in: Chesbroughh, Vanhaverbekew, Westj (Eds) Open Innovation; Researching a New Paradigm. Oxford University Press, London

Goldheim, D, Slowinski, G, Daniele, J, Hummel, E \& Tao, J. (2005). "Extracting Value From Intellectual Assets," ResearchTechnology Management, Number 2: 4348(6). Industrial Research Institute, Inc

Graaf, P. M. A, van den Eijkel, G. C., Vullings, H. J. L. M \& De Mol, B. A. J. M (1997). "A Decision-Driven Design of a Decision Support System in Anesthesia," Artificial Intelligence in Medicine, Vol. 11 (2): 141-153.

Hagelin, T. (2002). "A New Method to Value Intellectual Property," Quarterly Journal of the American Intellectual Property Law Association, Vol. 30 (3): 353-403.

Hanel, P. (2006). "Intellectual Property Rights Business Management Practices: a Survey of the Literature," Technovation, Vol. 26 (8): 895-931.

Jager, K., Peemöller, W. \& Rohde, M. (1989). "A Decision Support System for Planning Chemical Production of Active Ingredients in a Pharmaceutical Company," Engineering Costs and Production Economics, Vol. 17 (14): 377-387 
Kettelhut, M. C. (1991). "Using a DSS to Incorporate Expert Opinion in Strategic Product Development Funding Decisions," Information \& Management, Vol. 20 (5): 363371

King, K. (2002). "The Value of Intellectual Property, Intangible Assets and Goodwill," Journal of Intellectual Property Rights, Vol. 7: 245-248.

Kondo, E. K (1994). 'Patent Laws and Foreign Direct Investment: an Empirical Investigation,' Unpublished Phd Dissertation. Harvard University.

Kroll, H. \& Liefner, I. (2008). "Spin-Off Enterprises as A Means of Technology Commercialization in a Transforming Economy - Evidence from Three Universities in China," Technovation, 28: 298-313

Langrost, C., Martin, D., Dubois, C. \& Quazzoti, S. (2010). "Intellectual Property Valuation: How to Approach the Selection of an Appropriate Valuation Method," Journal of Intellectual Capital, Vol. 11 (4): 481-503.

Mard, M. J, Hyden, S. \& Rigby, J. S. (2000). "Intellectual Property Valuation," Financial Valuation Group, Los Angeles.

Matsuura, J. H (2004). "An Overview of Intellectual Property and Intangible Asset Valuation Models," Research Management Review, Vol. 14 (1): 1-10.

Mergermarket (2008). "M\&A Insights: Spotlight on Intellectual Property Rights," Available at Http:/ / Www.Crai.Com/ Uploadedfiles/ RELA TING MATERIALS/ Publications/ LAE/ MaInsights-Spotlight-Ip-Rights.Pdf (Accessed: 23 June 2011)

Meyer, M. S \& Tang, P. (2007). "Exploring the Value of Academic Patents: IP Management Practives in UK Universities and their Implications for Third-Stream Indicators," Scientometrics, Vol. 70 (2): 415-440.
MOHE (2008). "R\&D Products of Public Universities in Malaysia: Commercialized Products, Products with Commercial Potential, Patents and Trademarks (Until August 2008)," Department of Higher Education, Ministry of Higher Education (MOHE), Malaysia.

Moormann, J. \& Holtgreven, M. L. (1993). "An Approach for an Integrated DSS for Strategic Planning," Decision Support Systems, Vol, 10 (4): 401-411

Ndonzuau, F. N., Pirnay, F. \& Surlemont, B. (2002). "A Stage Model of Academic Spin-Off Creation," Technovation, Vol. 22 (5): 281-289.

Park, Y. \& Park, G. (2004). "A New Method for Technology Valuation in Monetary Value: Procedure and Application," Technovation, Vol. 24: 387-94.

Parker, S., Malstrom, E. M., Irwin, L. M. \& Ducote, G. (1994). "A Decision Support System for Personnel Scheduling in a Manufacturing Environment," Computers \& Industrial Engineering, Vol. 27 (1-4): 185-188

Pitkethly, R (2002). "The Valuation of Patents," Oxford: the Said Business School, University of Oxford. Available At Http:/ / Www.Oiprc.Ox.Ac.Uk/ RPWP0599.Pdf. (Accessed: 18 February 2009)

Reason, J. (1990). Human Error, Cambridge Univ. Press, Cambridge.

Reilly, R. F. (2009). "Valuation of IP During a Distressed Economy - Part I," The Licensing Journal, 12 - 20.

Reitzig, M. (2004). "Improving Patent Valuations for Management Purposes Validating New Indicators by Analyzing Application Rationales," Research Policy, Vol. 33: 939-957.

Roy, S. (2004). 'How Much is Your IP Worth?,' Available at Http:/ / Www.Hslicensing.Com/_Downloads/ 
Introductiontoipvaluation Hsl.Pdf.

(Accessed: 18 February 2009)

Salewicz, K. A. \& Nakayama, M. (2004). "Development of a Web-Based Decision Support System (DSS) for Managing Large International Rivers," Global Environmental Change Part A, Vol (14): 25-37

Samuel, D. (2007). "Intellectual Property Valuation: a Finance Perspective," Albany Law Review. Available at Http:/ / Www.Albanylawreview.Org/ Articles/ Samuel.Pdf (Accessed: 20 February 2009)

Shim, J. P., Warkentin, M., Courtney J. F., Power, D. J., Sharda, R. \& Carlsson, C. (2002). "Past, Present and Future of Decision Support Technology," Decision Support System, Vol. 33: 111-126.

Simon, H. A. (1977). The New Science of Management Decision, Chapter 2, PrenticeHall, USA, Pp. 39-81.

Smith, M. \& Hansen, F. (2002). "Managing Intellectual Property: a Strategic Point of View," Journal of Intellectual Capital, Vol. 3 (4): 336-374.

Sudarsanam, S., Sorwar, G. \& Marr, B. (2003), "Valuation of Intellectual Capital and Real Option Models," PMA Intellectual Capital Symposium, Cranfield University Cranfield, UK.

Turban, E. (1993). Decision Support and Expert Systems: Management Support Systems, 3rd Ed., Macmillan, New York.

UNICO. (2001). Annual Survey on University Technology Transfer Activities. NUBS

Van Den Berg, H. A. (2002). "Models of Intellectual Capital Valuation: a Comparative Evaluation," Available at Http:/ / Business.Queensu.Ca/ Kbe. (Accessed: 18 February 2009) 